\title{
Matrix Metalloproteinase-14
}

National Cancer Institute

\section{Source}

National Cancer Institute. Matrix Metalloproteinase-14. NCI Thesaurus. Code C41050.

Matrix metalloproteinase-14 (582 aa, $\sim 66 \mathrm{kDa}$ ) is encoded by the human MMP14 gene.

This protein is involved in both extracellular matrix proteolysis and the activation of 72

kDa type IV collagenase. 